\title{
Epidemiological and molecular analysis of a waterborne outbreak of norovirus GII.4
}

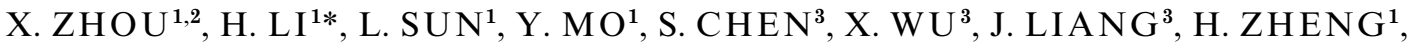 \\ C. KE ${ }^{1}$, J. K. VARMA ${ }^{4}$, J. D. KLENA ${ }^{4}$, Q. $\mathrm{CHEN}^{1}$, L. ZOU ${ }^{1}$ AND X. YANG ${ }^{1 *}$ \\ ${ }^{1}$ Guangdong Provincial Centre for Disease Control and Prevention, Guangdong, China \\ ${ }^{2}$ Guangzhou Red Cross Hospital Affiliated to Jinan University, Guangdong, China \\ ${ }^{3}$ Field Epidemiology Training Program of Guangdong Provincial Centre for Disease Control and Prevention, \\ Guangdong, China \\ ${ }^{4}$ China-US Collaborative Program on Emerging Infectious Diseases, Beijing, China and United States Centers \\ for Disease Control and Prevention, Atlanta, GA, USA
}

Received 12 January 2012; Final revision 17 January 2012; Accepted 15 February 2012; first published online 8 March 2012

\section{SUMMARY}

Contaminated water is one of the main sources of norovirus ( NoV) gastroenteritis outbreaks globally. Waterborne NoV outbreaks are infrequently attributed to GII.4 NoV. In September 2009, a NoV outbreak affected a small school in Guangdong Province, China. Epidemiological investigations indicated that household use water, supplied by a well, was the probable source (relative risk 1.9). NoV nucleic acid material in concentrated well-water samples was detected using real-time RT-PCR. Nucleotide sequences of NoV extracted from diarrhoea and well-water specimens were identical and had the greatest sequence identity to corresponding sequences from the epidemic strain GII.4-2006b. Our report documents the first laboratory-confirmed waterborne outbreak caused by GII.4 NoV genotype in China. Our investigations indicate that well water, intended exclusively for household use but not for consumption, caused this outbreak. The results of this report serve as a reminder that private well water intended for household use should be tested for NoV.

Key words: Gastroenteritis, norovirus, outbreak, well water.

\section{INTRODUCTION}

Non-bacterial gastroenteritis is a major health problem worldwide. With the application of new and sensitive diagnostic techniques, norovirus ( $\mathrm{NoV})$ is now recognized as the leading pathogen causing acute nonbacterial gastroenteritis in humans [1]. NoV belongs

\footnotetext{
* Author for correspondence: Dr H. Li or Professor X. Yang, Guangdong Provincial Centre for Disease Control and Prevention, Guangzhou, China, 510300.

(Email: gdcdclihui@163.com) [H. Li]

(Email: yangxingfen@cdcp.org.cn) [X. Yang]
}

to the Caliciviridae family. Of the five genotype groups (GG) of NoV, three (GI, GII, GIV) cause human illness. Based on the nucleic acid sequences of genes encoding the major capsid protein, there are eight genotypes in GI, 17 in GII, and one in GIV [2]. Many studies have shown that the GII.4 genotype is the main cause of $\mathrm{NoV}$ gastroenteritis in humans [3-7].

Contaminated water is one of the most important vehicles for $\mathrm{NoV}$ gastroenteritis outbreaks globally $[8,9]$. Detecting NoV RNA in water suspected of causing illness helps confirm that a gastroenteritis 
outbreak is due to NoV. Of the 41 waterborne gastrointestinal disease outbreaks reported during 1998-2003 in Finland, water specimens from 28 outbreaks were available for analysis; 10 of these were attributed to NoV [8]. Several other countries have also reported waterborne NoV outbreaks [3, 10].

Most waterborne NoV gastroenteritis outbreaks have been attributed to genotype GI [9-11], although genotypes GII.3, GII.6 [12], and GII.4 have been implicated. In September 2009, a gastroenteritis outbreak occurred in a small town school in Guangdong Province. Guangdong is a semi-tropical province located in southern China, with an estimated 110 million permanent and migrant residents. We report here the epidemiological, environmental, and laboratory investigation that identified NoV GII.4 contaminated well water as the source of this outbreak.

\section{MATERIALS AND METHODS}

\section{Outbreak description}

On 4 September 2009, an outbreak of gastroenteritis occurred in a school located in a small town in Guangdong Province. The school had 285 teachers, of whom $55 \%$ resided at the school; $50 \%$ of these dined in the school's restaurant; 5484 students $(99 \%$ residing at the school, $99 \%$ dining in the school's restaurant), and 85 staff members for cleaning and security. There had been no rain or large-scale gatherings at the school in the 2 weeks before the outbreak. About $80 \%$ of the school's daily water supply - water that was used for all purposes except drinkingwas from a single well. Water for drinking was supplied through a municipal water supply and was boiled first.

\section{Epidemiological investigation}

Cases were defined as patients with $\geqslant 3$ loose stools and/or vomiting in a 24-h period beginning from 31 August to 10 September, 2009. A retrospective cohort investigation using a standardized questionnaire was conducted on 10 September 2009, with 5795 people interviewed in-person and 59 by phone, with $100 \%$ enrolment. The exposed cohort was defined as those only served by water from the school well and the unexposed cohort was defined as all persons served only by the municipal water supply. Attack rates, relative risks (RR), and $95 \%$ confidence intervals (CI) were calculated using SPSS v. 13.0 (SPSS Inc., USA).
A $P$ value of $<0.05$ was considered statistically significant. Because $\mathrm{NoV}$ is also able to be transmitted through contaminated food, we also investigated common food exposures in students and teachers.

\section{Environmental investigation}

We examined the well construction log, current well and chlorination conditions, and potential sources of contamination. The township Centre for Disease Control (CDC) tested the well water for total aerobic bacteria and faecal coliforms using the most probable number (MPN) technique. Standard laboratory methods were used for bacteriological investigations.

\section{Diarrhoeal specimen collection and processing}

Diarrhoeal specimens were collected on 8 and 10 September 2009, from patients meeting the case definition; faecal and rectal swabs were collected from 19 students and nine teachers. Faecal specimens were diluted with Hank's solution to make a 10-20\% w/v suspension. RNA extraction was performed after centrifugation ( $926 \boldsymbol{g}$ for $2 \mathrm{~min}$ ) to clarify supernatants. Rectal swabs were placed in Hank's solution vortexed for $2 \mathrm{~min}$, subseqently discarding the swabs. Rectal swab suspensions were centrifuged $(926 \boldsymbol{g}$ for $3 \mathrm{~min}$ ) to clarify the supernatant before RNA extraction.

\section{Water specimen collection and processing}

Water samples ranging in volume from 0.8 to 2.51 were collected directly from the well $(n=1)$ and from tap water pumped from the well $(n=2)$ on 10 September 2009, prior to chlorination. On 16 September, after chlorination of the well by the township CDC, additional water samples were collected directly from the well $(n=1)$, from tap water pumped from the well $(n=2)$, from a storage tank holding well water $(n=1)$, from municipal tap water $(n=1)$ and from river water $(n=1) . \mathrm{MgCl}_{2}$ was added to the water specimens to make a final concentration of $0.05 \mathrm{M}$, and the $\mathrm{pH}$ was adjusted to $3 \cdot 0$. Water specimens were filtered through a mixed cellulose ester membrane [13] (Advantec, USA) and eluted with buffer containing $0.05 \mathrm{~m}$ glycine and $3 \%$ beef extract (pH 9.5). Addition of $40 \%$ PEG6000 and $5 \mathrm{~m} \mathrm{NaCl}$ (final concentration $10 \%$ and $0.3 \mathrm{M}$, respectively) was followed by incubation $\left(12 \mathrm{~h}\right.$ at $\left.4{ }^{\circ} \mathrm{C}\right)$ and 


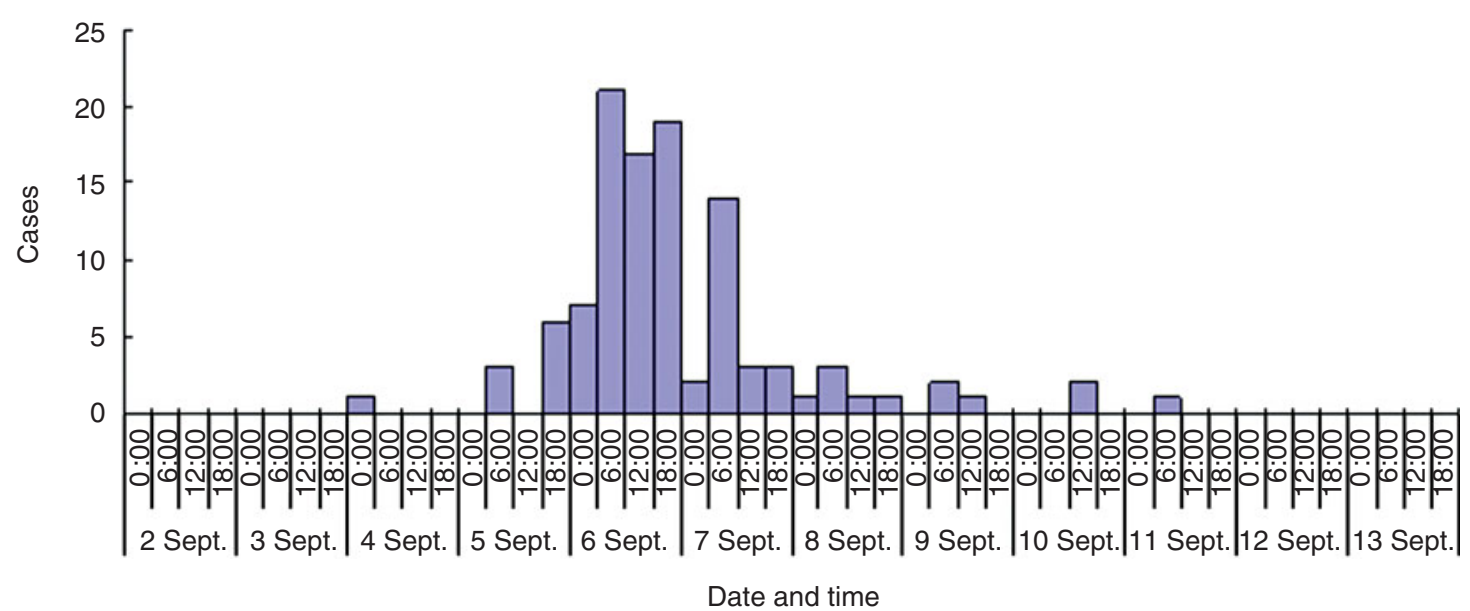

Fig. 1 [colour online]. Date and times of illness onset for cases associated with a norovirus outbreak in Guangdong, China, 2009.

centrifugation (10286 g for $30 \mathrm{~min}$ ). Pellets were resuspended in $1 \mathrm{ml}$ of RNase-free water (Takara, Japan).

\section{RNA extraction}

Viral RNA was extracted from faecal and water samples using a QIAamp Viral RNA Mini kit (Qiagen, Germany) according to the manufacturer's protocol.

\section{Absolute and quantitative real-time RT-PCR detection}

For detection of $\mathrm{NoV}$, we used primers $\mathrm{COG} 2 \mathrm{~F} /$ COG2R as described previously [14]. Real-time RT-PCR was conducted in an ABI.7500 Fast RealTime PCR System (Applied Biosystems Inc., USA) using Perfect Real Time reagent (Takara). Realtime RT-PCR was performed in a $20 \mu 1$ volume as described previously [14]. Fluorescent signals were recorded at $72{ }^{\circ} \mathrm{C}$. Standard curves for determining the amount of virus in water specimens were generated by serially diluting plasmids containing NoV GI and GII PCR products. The formula $\mathrm{Ct}=$ $40.991-3.494 \times \log x$ (where $\mathrm{Ct}$ is the cycle threshold and $x$ represents the viral quantity, copies $/ \mu 1$ ) was used for quantitative analysis of NoV. The correlation coefficient of the curve was 0.998. The percentage recovery, which is equal to the quantity of virus after concentration divided by the quantity of virus before concentration, could then be calculated.

\section{NoV genotyping by nucleotide sequence analysis}

Amplified products from two students, two teachers and the well-water specimens were selected for nucleotide sequence analysis. The primers JV13I/ JV12Y and SKF/SKR designed by Vennema et al. [15] and Kojima et al. [16] were used to amplify portions of the genes encoding the RNA-dependent RNA polymerase (RdRp, nt 4279-4605) and capsid protein (nt 5046-5398), respectively. Bidirectional sequencing of the amplified PCR products was achieved using BigDye $3 \cdot 1$ chemistry (Applied Biosystems Inc.) using an ABI PRISM 3130 DNA analyser. DNA sequences were aligned using the Bioedit program and construction of phylogenetic trees was performed using MEGA 4.0 software. Reference viral gene sequences were provided by National Institute for Public Health and the Environment, The Netherlands. Nucleotide sequences were assigned Genbank accession numbers HM627865-HM627869 for RdRp, and HM627870HM627874 for capsid sequences.

\section{RESULTS}

\section{Epidemiological investigation}

The first case of gastroenteritis occurred on 4 September 2009, with the peak incidence noted on 6 September (Fig. 1). The overall attack rate during this outbreak was $1.8 \%$ with $1.7 \%(92 / 5484)$ of students and $5 \cdot 6 \%(16 / 285)$ of teachers affected. In total, $2.0 \%(62 / 3153)$ of the entire male, and $1.8 \%$ (46/2616) of the female school population were affected. The outbreak did not extend to the adjacent 
residential area, where the incidence of diarrhoea remained stable. Symptoms included diarrhoea (100\%), abdominal pain $(82 \%)$, vomiting $(72 \%)$, nausea (61\%), flatulence $(51 \%)$, and fever $(38 \%)$ ). In most cases, symptoms were mild, self-limiting, and lasted a median of 2 days. Some of the rooms (serving 2320 people) in the school complex received only untreated well water, other rooms (serving 1373 people) received only municipal tap water; the remaining rooms received water from both sources. An investigation revealed that all foods were boiled with municipal tap water but cleaned with untreated well water before cooking. Students, teachers and staff consumed the same foods. No risk factor related to food consumption was identified. Students and teachers reported drinking boiled tap water. The epidemiological investigation showed that the attack rates in the dormitory building supplied with untreated well water and the dormitory building supplied with municipal tap water were $2.0 \%$ and $1.1 \%$, respectively. Exposure to well water had a RR of $1.9(95 \% \mathrm{CI}$ $1 \cdot 1-3 \cdot 4)$, indicating that well water was a risk factor for the outbreak. Well water was disinfected with chlorine on 10 September; no new cases were reported after 12 September (Fig. 1).

\section{Environmental investigation}

Several sources of water to the school were investigated for NoV contamination. Routinely, untreated well water was first pumped into a storage tank and, from there, pumped to rooms through pipes as required. The well supplying this water was approximately $30 \mathrm{~m}$ deep; a drainage line at the bottom of the well leads to a place $20 \mathrm{~m}$ lower than the bottom of a nearby river. The well surface was completely covered, and the environment in the immediate vicinity was cluttered with debris. Microbiological investigation of the well water indicated faecal contamination: there were $2 \cdot 2 \times 10^{3}$ colony-forming units (c.f.u.) $/ \mathrm{ml}$ of aerobic bacteria and a large number of faecal coliforms, with an MPN count of 72/100 ml. Further environmental investigation was unable to determine the source of contamination.

\section{Real-time RT-PCR results of the patient and water specimens}

RNA samples from the students $(8 / 19,42 \%)$ and teachers $(5 / 9,56 \%)$ tested positive for NoV. Samples from the well (well water and pumped well water)
Table 1. Real-time RT-PCR detection of norovirus $R N A$ in well-water samples

\begin{tabular}{lll}
\hline \hline Specimen & $\begin{array}{l}\text { No. of } \\
\text { samples }\end{array}$ & $\begin{array}{l}\text { Detection } \\
\text { of norovirus } \\
\text { RNA }\end{array}$ \\
\hline $\begin{array}{l}\text { Before chlorination } \\
\text { Well water }\end{array}$ & 1 & Positive \\
Tap water* & 2 & Positive \\
$\begin{array}{l}\text { After chlorination } \\
\text { Well water }\end{array}$ & 1 & Positive† \\
Tank water* & 1 & Negative \\
Tap water* & 2 & Negative \\
Municipal water supply & 1 & Negative \\
River water & 1 & Negative \\
\hline \hline
\end{tabular}

* The source of the water is from the well, tank water is well water that was pumped to a holding tank; tap water indicates water pumped from the tank into the school water supply on demand.

$\dagger$ Well-water specimens were much weaker than before.

were also positive for NoV by real-time RT-PCR before disinfection with chlorine (Table 1). After disinfection, well water remained positive although much weaker than before (Fig. 2); however, the storage tank and pumped water from the well tested negative. Municipal tap water and river water were negative for NoV (Table 1).

\section{Quantification of NoV in water specimens}

We detected 215 copies $/ \mu 1$ of $\mathrm{NoV}$ in well water and water pumped from the well (tap water samples 1 and 2) before sample concentration. After $2500 \times$ concentration through a mixed cellulose ester membrane, up to $10^{5}$ copies $/ \mu 1 \mathrm{NoV}$ could be detected. Two pumped well-water samples (tap water samples 1 and 2) that were concentrated 800 times contained between $2.5 \times 10^{3}$ and $5 \cdot 0 \times 10^{3}$ copies $/ \mu 1$, respectively (Table 2). Concentrating municipal or river water did not show a positive result in detection of NoV.

\section{NoV genotyping results}

Segments of the genes encoding NoV RdRp and capsid proteins were amplified and the DNA sequences were analysed from samples collected from two students, two teachers, and well water. The concentration of $\mathrm{NoV}$ in positive pumped well-water samples was not enough for sequencing. Comparative 
Table 2. Quantity and yields of norovirus recovered from water samples

\begin{tabular}{|c|c|c|c|c|c|c|c|}
\hline & \multicolumn{3}{|c|}{ Before concentration } & \multicolumn{3}{|c|}{ After concentration } & \multirow[b]{2}{*}{$\begin{array}{l}\text { Yields } \\
(\%)\end{array}$} \\
\hline & $\begin{array}{l}\text { Volume } \\
(\mathrm{ml})\end{array}$ & $\begin{array}{l}\mathrm{Ct} \\
\text { value }\end{array}$ & $\begin{array}{l}\text { Viral } \\
\text { quantity } \\
(\operatorname{copies} / \mu \mathrm{l})\end{array}$ & $\begin{array}{l}\text { Volume } \\
(\mathrm{ml})\end{array}$ & $\begin{array}{l}\mathrm{Ct} \\
\text { value }\end{array}$ & $\begin{array}{l}\text { Viral } \\
\text { quantity } \\
\text { (copies } / \mu 1)\end{array}$ & \\
\hline Well water & 2500 & $32 \cdot 83$ & 215 & 1 & $23 \cdot 61$ & $10^{5}$ & $17 \cdot 41$ \\
\hline Tap water sample $1 *$ & 800 & $32 \cdot 81$ & 215 & 1 & $29 \cdot 06$ & $2 \cdot 5 \times 10^{3}$ & $1 \cdot 48$ \\
\hline Tap water sample $2 *$ & 800 & $32 \cdot 90$ & 215 & 1 & $28 \cdot 13$ & $5 \cdot 0 \times 10^{3}$ & $2 \cdot 90$ \\
\hline
\end{tabular}

Ct, Cycle threshold.

* The source of the water is from the well; tap water indicates water pumped from the tank into the school water supply on demand.

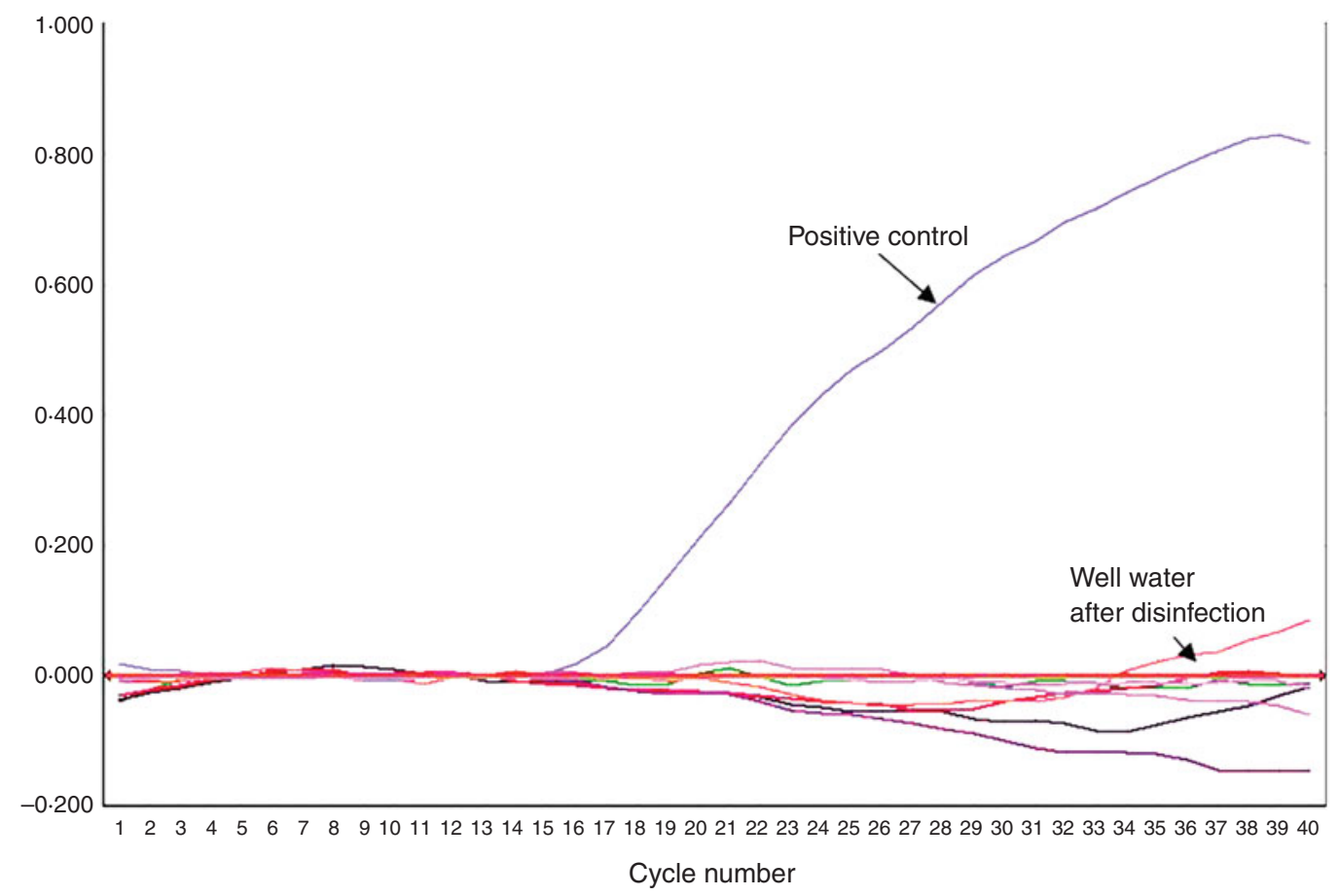

Fig. 2 [colour online]. Real-time RT-PCR result of water samples after disinfection.

sequence analysis showed that all of the NoV gene sequences from humans and water were indistinguishable. Phylogenetic analysis against a collection of reference sequences representing a variety of NoV genotypes showed that the virus responsible for this outbreak was classified as a genotype GII.4 NoV, with the closest identity to GII.4-2006b (AB294793 and EF126966; Figs 3 and 4).

\section{DISCUSSION}

We report the results of a large-scale NoV gastroenteritis outbreak in a school located in Guangdong,
China caused by consumption of contaminated well water. Several lines of evidence support NoV-contaminated well water as the source of this outbreak. First, we detected NoV in human and wellwater specimens, and sequencing of two viral genes indicated these were indistinguishable between the samples. Second, the outbreak was controlled by disinfection of the well. Third, the attack rate was 1.9 times higher in those exposed to well water (untreated) compared to those exposed to municipal (treated) tap water. Finally, students, teachers and staff ate the same foods; no risk factor related to food consumption was identified. 


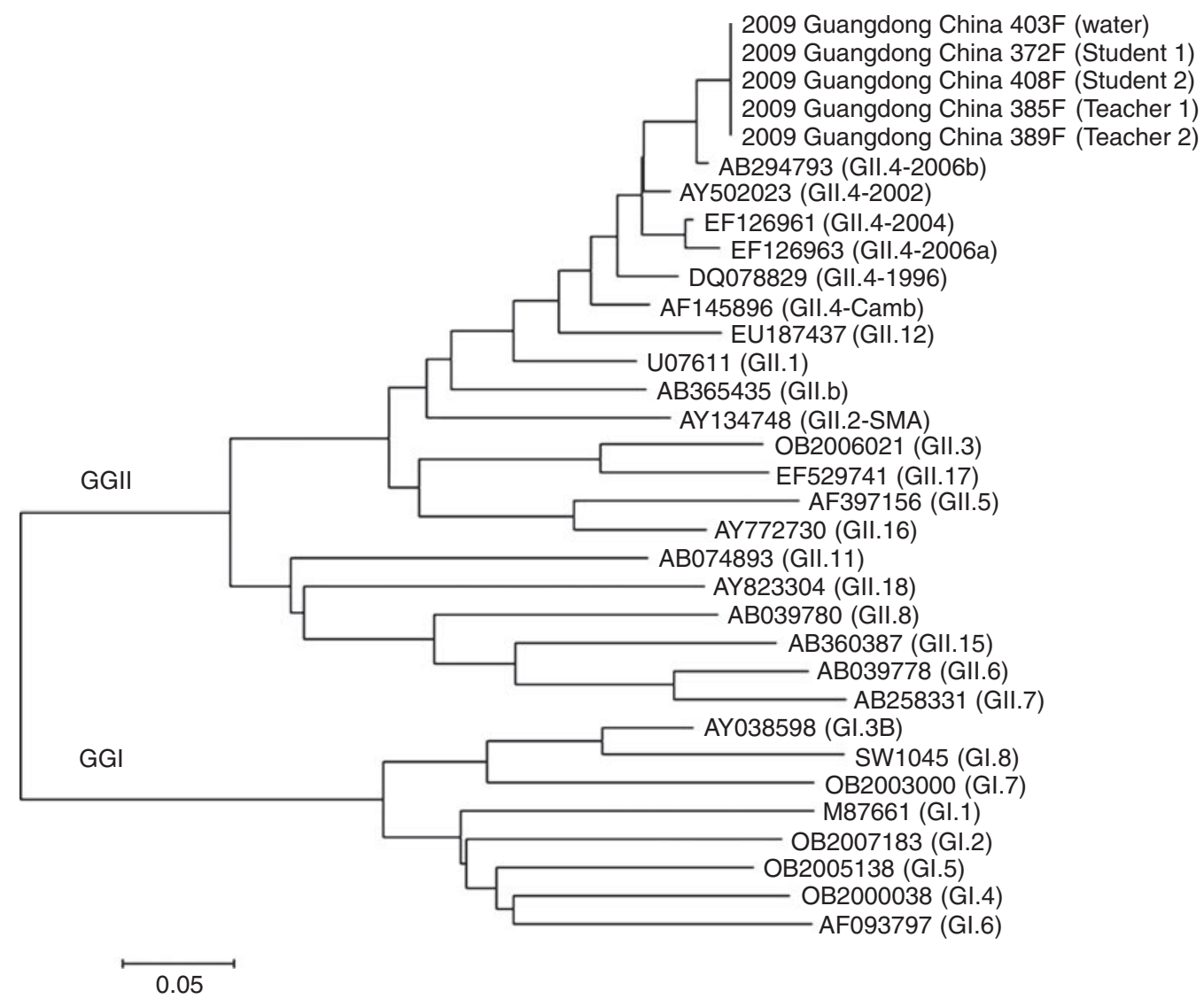

Fig. 3. Phylogenetic tree based on nucleotide sequence of the norovirus RNA-dependent polymerase (nt 4573-4584). The reference strain designation is the Genbank accession number followed by the genotype designation (in parentheses).

Although GII.4 is the most common cause of NoV infection worldwide [5, 17], waterborne NoV gastroenteritis outbreaks are normally attributed to the GI genotype $[9,10,12]$, less frequently to genotypes GII.3 and GII.6 [11], and infrequently to GII.4. Maunula et al. [8] postulated that this may be due to differential stability among unique genotypes. However, no direct evidence has yet been presented that confirms the differences in the frequency of waterborne NoV GII.4 and GI infections are due to differences in NoV genotype stability.

$\mathrm{NoV}$ is one of the most important waterborne viruses causing gastroenteritis. There are recent reports of NoV in sewage [18], river water [19] and even drinking water [20]. Often, it is necessary to concentrate the virus in specimens of water because the quantity of virus is small. Membranes (e.g. positively charged [21], negatively charged [22], and cellulose ester [23]) are commonly used for this purpose. In this outbreak, the viral copy number in well water and water pumped from the well was $215 / \mu 1$ before concentration and $2.5 \times 10^{3}-10^{5} / \mu 1$ after concentration. The percentage recovery from well water $(17 \cdot 41 \%)$ was much higher than that from the pumped well water [specimen $1(2 \cdot 90 \%)$ and specimen $2(1.48 \%)]$. It is likely that the total amount of virus recovered was influenced by differences in the volume of the water samples $(2500 \mathrm{ml}$ for the well water as opposed to $800 \mathrm{ml}$ for each of the two pumped wellwater specimens). This is supported by a study showing that the initial concentration of virus greatly affects the recovery of virus [21]. Most studies report recovery rates from $3 \cdot 3 \%$ [22] to $45 \%$ [24]. In this outbreak, the recovery of virus from cellulose ester membranes was in good agreement with data from similar studies [21, 22].

One limitation of our study is that we were unable to identify the contamination source of the well. An on-site inspection found no specific source of contamination around the well and no evidence of intentional contamination. The well was completely covered and $30 \mathrm{~m}$ deep, making direct animal entry virtually impossible. The environment in the 


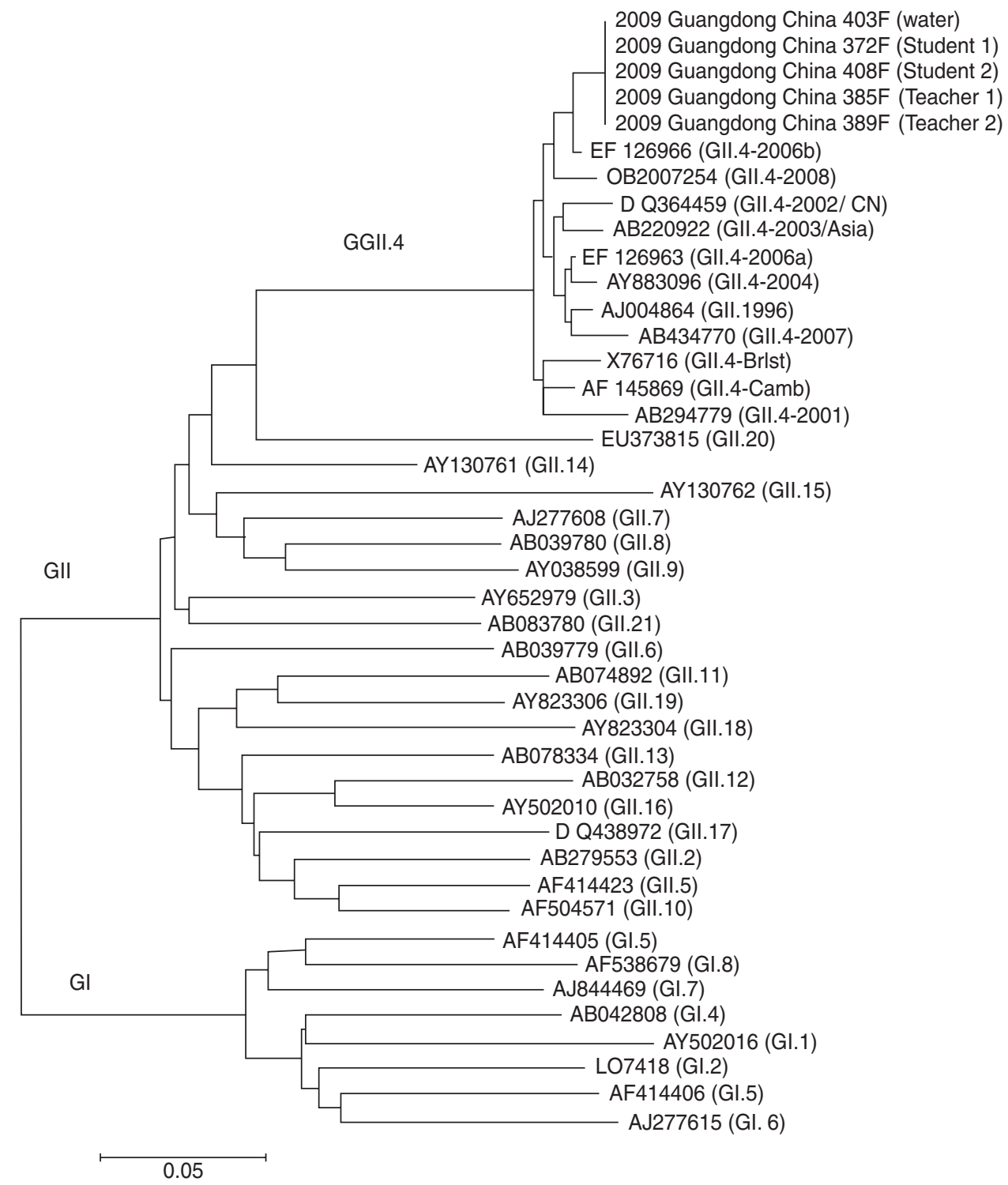

Fig. 4. Phylogenetic tree based on the nucleotide sequence of the norovirus capsid gene (nt 5065-5366). The strain designation is the Genbank accession number followed by the genotype designation (in parentheses).

immediate vicinity of the well was cluttered with debris, thus it might be possible that leaching from a source contributing to this debris contributed to the contamination.

This is the first report from China in which laboratory studies have been used to confirm the source of a waterborne outbreak of NoV gastroenteritis. Both laboratory and epidemiological evidence indicated that the school's well water was contaminated by NoV GII.4, an uncommon genotype for waterborne NoV outbreaks. Throughout the world, waterborne diseases remain an important cause of morbidity and mortality [25]. NoV is an important waterborne pathogen in contaminated water [26].
Provincial authorities should routinely monitor water systems in schools for NoV and repair damaged water systems as necessary. This will reduce morbidity and mortality in children, and allow schools to focus on education.

\section{ACKNOWLEDGEMENTS}

This research was financially supported by Guangdong Science and Technology Department (No. 2007A0300007-7). We acknowledge the contributions of Professor Duan Zhaojun and Dr Jin Miao from the Chinese Centre for Disease Control and Prevention for sequencing the capsid gene of 
the samples. We also acknowledge Professor $\mathrm{H}$. Vennema of the National Institute for Public Health and the Environment of The Netherlands for providing reference viral gene sequences.

\section{DECLARATION OF INTEREST}

None.

\section{REFERENCES}

1. Fang ZY. The strategy for norovirus gastroenteritis prevention and control. Chinese Journal of Epidemiology 2007; 28 : 222-223.

2. Zheng DP, et al. Norovirus classification and proposed strain nomenclature. Virology 2006; 346: 312-323.

3. Koek AG, et al. Additional value of typing noroviruses in gastroenteritis outbreaks in Amsterdam, The Netherlands. Journal of Clinical Virology 2006; 35: 167-172.

4. Dey SK, et al. Molecular and epidemiological trend of norovirus associated gastroenteritis in Dhaka city, Bangladesh. Journal of Clinical Virology 2007; 40: 218-223.

5. Wu J, et al. Study on the epidemiologic characteristics of norovirus infection in Beijing. Chinese Journal of Epidemiology 2007; 28: 671-675.

6. Noda M, Fukuda S, Nishio O. Statistical analysis of attack rate in norovirus foodborne outbreaks. International Journal of Food Microbiology 2008; 122: 216-220.

7. Reuter G, Pankovics P, Szücs G. Genetic drift of norovirus genotype GII-4 in seven consecutive epidemic seasons in Hungary. Journal of Clinical Virology 2008; 42: $135-140$.

8. Maunula L, Miettinen IT, von Bonsdorff CH. Norovirus outbreaks from drinking water. Emerging Infectious Diseases 2005; 11: 1716-1721.

9. Hewitt $\mathbf{J}$, et al. Gastroenteritis outbreak caused by waterborne norovirus at a New Zealand ski resort. Applied and Environmental Microbiology 2007; 73: 7853-7857.

10. Lysén M, et al. Genetic diversity among food-borne and waterborne norovirus strains causing outbreaks in Sweden. Journal of Clinical Microbiology 2009; 47: 2411-2418.

11. Kim SH, et al. Outbreaks of gastroenteritis that occurred during school excursions in Korea were associated with several waterborne strains of norovirus. Journal of Clinical Microbiology 2005; 43: 4836-4839.

12. Parshionikar SU, et al. Waterborne outbreak of gastroenteritis associated with a norovirus. Applied and Environmental Microbiology 2003; 69: 5263-5268.
13. Zhang CM, et al. Comparison of concentration methods for enteroviruses from environmental waters. China Water and Wastewater 2007; 23: 36-39.

14. Kageyama T, et al. Broadly reactive and highly sensitive assay for Norwalk-like viruses based on real-time quantitative reverse transcription-PCR. Journal of Clinical Microbiology 2003; 41: 1548-1557.

15. Vennema H, de Bruin E, Koopmans M. Rational optimization of generic primers used for Norwalk-like virus detection by reverse transcriptase polymerase chain reaction. Journal of Clinical Virology 2002; 25: 233-235.

16. Kojima S, et al. Genogroup-specific PCR primers for detection of Norwalk-like viruses. Journal of Virological Methods 2002; 100: 107-114.

17. Maunula L, Von Bonsdorff CH. Norovirus genotypes causing gastroenteritis outbreaks in Finland 1998-2002. Journal of Clinical Virology 2005; 34: 186-194.

18. Katayama H, et al. One-year monthly quantitative survey of noroviruses, enteroviruses, and adenoviruses in wastewater collected from six plants in Japan. Water Research 2008; 42: 1441-1448.

19. Lee C, Kim S-J. The genetic diversity of human noroviruses detected in river water in Korea. Water Research 2008; 42: 4477-4484.

20. Gutiérrez MF, et al. Presence of viral proteins in drinkable water- sufficient condition to consider water a vector for viral transmission? Water Research 2007; 41 : 373-378.

21. Xiaohong $\mathbf{Z h}$, et al. Concentration and absolute quantitatively detection of the norovirus of the water specimens. Journal of Tropical Medicine 2010; 10: 137-140.

22. Victoria M, et al. Evaluation of an adsorption-elution method for detection of astrovirus and norovirus in environmental waters. Journal of Virological Methods 2009; 156: 73-76.

23. Zhang CM, et al. Study on membrane adsorptionelution method for concentration of enteroviruses from environmental waters. Huan jing ke xue 2007; 28 : 1543-1547.

24. Haramoto E, et al. Recovery of naked viral genomes in water by virus concentration methods. Journal of Virological Methods 2007; 142: 169-173.

25. Yoder JS, et al. Surveillance for waterborne disease and outbreaks associated with recreational water use and other aquatic facility-associated health events United States, 2005-2006. Morbidity and Mortality Weekly Report 2008; 57: 1-29.

26. Yoder J, et al. Surveillance for waterborne disease and outbreaks associated with drinking water and water not intended for drinking - United States, 2005-2006. Morbidity and Mortality Weekly Report 2008; 57: 39-62. 